\title{
DIREKTIUSED KÕNEAKTID NING NENDE KASUTAMISE DÜNAAMIKA ISA JA EMA KÕNES: JUHTUMIUURING
}

\author{
Helen Kõrgesaar
}

\begin{abstract}
Ülevaade. Artikli eesmärk on anda ülevaade direktiividest eesti lapsele suunatud kõnes. Vaatluse all on kaks sama pere kooliealist last ja nende dialoogid mõlema vanemaga eraldi. Meetodina on kasutatud pikiuuringut (üht last on lindistatud regulaarselt vanuses 7-10 eluaastat, teist vanuses 10-14 eluaastat), mis hõlmab 16 tunni jagu audiomaterjali. Vanemate kõne direktiivsed lausungid on liigitatud otsesteks ja kaudseteks käskudeks, keeldudeks, kõneleja soovitud tegevuse väljendusteks, palveteks, soovideks, soovitusteks, ettepanekuteks, hoiatusteks ja kultuurinormi edastusteks. On võrreldud eri tüüpi direktiivide kasutamist ema ja isa kõnes ning vaadeldud direktiivide kasutamise dünaamikat laste kasvades ning suhtlusolukorriti. Selgub, et ehkki direktiivide hulk hoidjakeeles aja jooksul väheneb, kasutavad nii isa kui ka ema kõige sagedamini siiski otseseid käske.
\end{abstract}

Võtmesõnad: hoidjakeel, lapsele suunatud kõne, eesti keel

\section{Sissejuhatus}

Eesti lapsele suunatud kõne ${ }^{1}$ uurimine on pikka aega keskendunud emade keelekasutusele, alles viimasel ajal on mõnevõrra uuritud ka isade kõnet (Rääbis 2012) ja võrreldud seda emade omaga (Kõrgesaar 2014b). Enamik seniseid hoidjakeele uurimusi keskendub vanemate kõnele väikelastega, kes on alles keeleomandamise algstaadiumis (Argus 2010, Argus, Kõrgesaar 2012, Argus, Kõrgesaar 2014, Kõrgesaar 2014a). Arengupsühholoogia valdkonnas on mõnevõrra uuritud ka lasteaiavõi kooliealistele lastele suunatud kõnet (Tulviste 2001, Tulviste 2003, Tulviste jt 2003, Tulviste jt 2004), ent keeleteaduse vaatenurgast on niisuguseid uurimusi vaid üksikuid (Tamm jt 2014, Kõrgesaar 2014b).

Kui varem väideti hoidjakeeleuurimustes üsna kindlalt, et lastega räägivad kõige rohkem just emad ja nimelt emade hoidjakeel on lastele keele omandamise

Laste- ja hoidjakeele terminite kohta vt Kõrgesaar, Kapanen 2015 siinses kogumikus. 
juures kõige suuremaks toeks, siis tänapäevasemad uurimused kinnitavad, et ka isade hoidjakeelel on laste kõne arengus oma suur osa. Isade ja emade hoidjakeele keelekoguseid $^{2}$ uurides on leitud, et isad kõnelevad lapsega samasuguses mahus nagu emad, samuti on väidetud, et isad ärgitavad lapsi rohkem vestlema ning arendavad ja laiendavad nende sõnavara. (Snow 1977, Olson 1986, Matychuk 2005, Leech jt 2013, Pratt jt 1992)

Elizabeth Hill väidab, et üldiselt on varasemad uurimused kinnitanud, et emad ilmutavad lastega kõneldes suuremat tundlikkust ja vastavad lastele rohkem. Ta viitab ka Campbell Leaperi, Kristin J. Andersoni ja Paul Sandersi uurimusele (1998: 3), milles on leitud, et emad on lastega suheldes jutukamad, samal ajal kui isad kasutavad pigem direktiivsemaid vestlusstrateegiaid ja vastavalt rohkeid imperatiivivorme. Oma töös on Hill muuhulgas võrrelnud isa ja ema kasutatud keelekoguseid ning kasutatud käske ja keelde. Ühe kuueaastase lapse ja tema mõlema vanemaga peetud kahe dialoogi kõneandmete analüüsi põhjal leidis kinnitust oletus, et emalt lapsele suunatud keele kogus on märksa suurem kui isa oma, hõlmates ligi kaks korda rohkem lausungeid, mis on ka isa lausungitest pikemad. Küll aga ei leidnud kinnitust seisukoht, nagu oleks isa lapsega direktiivsem kui ema. (Hill 2009: 163-165, 168)

Kuivõrd siinkirjutaja varasemast uurimusest (Kõrgesaar 2014b) ilmnes, et isad ja emad kasutavad lastega kõneldes ühesuuruseid keelekoguseid ning ka kõne funktsionaalne jaotus on üsnagi sarnane (nii isade kui ka emade kõnes esineb laias laastus ühepalju küsimusi, väiteid ja käske), keskendub seekordne käsitlus kitsamalt direktiividele ja püüab välja selgitada, kuidas need isade ja emade kõnes jagunevad. Artikli teises osas antakse ülevaade direktiivi mõistest, kolmas osa kirjeldab uurimismeetodit ja andmestikku ning seejärel vaadeldakse direktiivide kasutussagedust suhtlusolukorriti, võrreldakse eri tüüpi direktiivide osakaalu isade ja emade kõnes, samuti direktiivide kasutamise dünaamikat eri vanuses lapsega kõneldes.

Vanema kõne direktiividel on kindel eesmärk eelkõige suunata ja juhtida lapse käitumist, kuid mitte ainult - direktiivide abil saab kaudselt kaasa aidata ka lapse sõnavara arengule (nt Too emmele see suur punane pall sealt issi töölaua alt!) ja neil on oluline roll lapse ühiskonda sotsialiseerimise protsessis. Eri tüüpi direktiivide kasutamine viitab suhtluse komplekssemaks muutumisele. Võib oletada, et väikese lapsega kasutatakse pigem otseseid käske ja lapse vanuse kasvades võib suureneda kaudsete direktiivide hulk, nt edastatakse käsk hoopis üldise kultuurinormina (enne sööki pestakse käsi) või hoiatusena (kui sa seal kaua turnid, kukud alla).

\section{Direktiivi mõistest ja varasematest käsitlustest}

Direktiivi mõiste üle on palju vaieldud. Alexandra Craven ja Jonathan Potter (2010: 420) defineerivad direktiivi kui käsku, öeldes, et direktiiv on "kõneakt, mille abil üks vestluse osapool käsib [tells] teisel midagi teha”. Samamoodi sõnastab direktiivi Hill (2009: 165), lisades sõnale 'käsib' ka sõna 'nõuab' (“the speaker is telling or ordering someone to do something”). Neile kahele definitsioonile vastanduvad Traci Curl ja Paul Drew, kelle järgi palve (ingl request) on "kõneakt, mille abil üks vestluse osapool palub [asks] teisel midagi teha” (Curl, Drew 2008: 12). Kõneaktiteooria

2 Keelekoguse (ingl amount of language) all on siinses artiklis silmas peetud vestluse ühe osalise lausungite hulka ühe tunni pikkuses spontaanse kõne lindistuses. 
looja John Searle käsitab direktiivi ülemmõistena, mille alla koondab soovi, käsu, käskluse, küsimuse, anumise, palve jne. Direktiivi eesmärk on Searle’i (1979: 5) järgi panna kuulaja midagi tegema. Susan Ervin-Tripp (1976: 29) on pakkunud välja oma lahenduse, milles toob ära kuut tüüpi direktiivid. Esitan need järgnevalt koos eesti näidetega.

- Vajadust väljendavad deklaratiivid (need statements), nt Mul on tikke vaja.

- Otsesed käsud e imperatiivid (imperatives), nt Anna mulle tikud! või vaeglause Tikud!

- Varjatud imperatiivid (embedded imperatives), nt Kas sa saaksid mulle tikke anda? - juhud, kus tegevuse subjekt, objekt, tegevus ja sageli ka kasusaaja on väljendatud niisama selgesõnaliselt kui otseses käsus, kuid need on varjatud muude semantiliste ja süntaktiliste tunnuste taha.

- Lubavad/võimaldavad direktiivid (permission directives), nt Kas ma tohiksin tikke paluda? - suhtlusolukord, mille keeleline vormistus ei jäta vestluspartnerile muud võimalust kui nõutud tegevus teha.

- Küsimusekujulised direktiivid (question directives), nt Tikke on?, mis ei täpsusta soovitud tegevust.

- Vihjed (hints), nt Kõik tikud on otsas.

Nagu eeltoodust nähtub, iseloomustab kõiki nelja direktiivi definitsiooni kõneleja soov vestluspartnerit midagi tegema panna, erinevused ilmnevad pigem selles, mida eri autorid on tegemapanemise all silmas pidanud. Kui Craven ja Potter (2010) ning Curl ja Drew (2008) on välja toonud vaid ühe viisi või võimaluse (käsu ja palve) oma eesmärgi saavutamiseks, siis oluliselt varasemast ajast pärinevad Searle’i (1979) ja Ervin-Trippi (1976) käsitlused võimaldavad mitmekülgsemat lähenemist, kuivõrd hõlmavad kõiki kõneakte, millel on üks eesmärk (panna vestluse teine osapool midagi tegema), ehkki keelelised vormistusvahendid on erinevad (küsimuse vormis direktiivid, vihjed jne). Mainitud põhjusel näivad viimased lähenemised hoidjakeele direktiivide uurimiseks rohkem sobivat.

Direktiivide liigitamist märksa laiemalt kui vaid käskudeks-palveteks toetab ka värske lähenemine, mille on välja pakkunud Ursula Stephany, Ayhan Aksu-Koç ja Maria D. Voeikova (2013: 11). Direktiivid liigitatakse selles järgmiselt (lisatud on taas eesti näited):

- käsud (commands), nt Tule sïa!

- $\quad$ keelud (prohibitions), nt Ära puutu!

- $\quad$ soovid (speaker's wish), nt Ma tahan seda!

- $\quad$ soovitused (suggestions), nt Sa pead ema sõna kuulama. Sa võiks nüüd koju minema hakata.

- $\quad$ ettepanekud (hortatives), nt Hakkame nüüd sööma!

- hoiatused (warnings), nt Kui sa auto maha pillad, sïs see kaob ära.

- $\quad$ kultuurinormi edastamine (statements of social rules), nt Pärast tualetis käimist pestakse käsi! Väikeseid lapsi ei tohi kiusata!

- kõneleja soovitud tegevuse väljendus (statements of an addressee's desired action), nt Seda ei puutu! 3

- $\quad$ kõneleja soovitud tegevus või seisund, mis on seotud kolmanda osalisega (statement of state of the third part), nt Las see olla seal!

3 Erinevus keelust (Ära puutu!) seisneb vormistuses. Kõneleja soovitud tegevust on väljendatud deklaratiiviga, 
"Eesti keele grammatika” (EKG II: 174-176) järgi loetakse käsklauseks (silmas on peetud pigem kirjalikku teksti ja lauset, mitte niivõrd suulise kõne lausungit) lausetüüpi, "mille grammatiline ehitus on kohandatud ülesandele väljendada käsku (palvet, üleskutset, nõuet, kategoorilist käsku) lausega märgitud sündmuse teostamiseks”. Eristatakse ka negatiivset käsku ehk keeldu (Ära muutu jämedaks!) ja tuuakse välja viisid, kuidas käsku vormistada: imperatiivne verbivorm otsese käsu puhul (Osta poest leiba!) ja jussiivne vahendatud käsu puhul (Rohelised kogunegu plaanikomitee ette). Samuti on mainitud võimalust esitada käsku küsimuse (Kas sa tõused juba ükskord?) või hüüdfraaslausena (Stopp!) ja keeldu üttelausena (Ma lähen nüüd lõplikult minema. - Armas laps!).

Helle Metslang (2004) on uurinud suulise kõne (argikõne) direktiivide väljendamise võimalusi ja esitanud direktiivide väljendamise keelelised vahendid. Metslang selgitab, et otseseid käske moodustatakse enamasti imperatiivse (Anna see nuga siia), vahendatud käske aga jussiivse verbiga (Pangu obune ette). me-lõpulise verbivormi kasutamise kohta (Tule Tallinna ja lähme Märdi juurde sauna!) ütleb Metslang, et selle semantiline väli hõlmab käsku, soovitust ja kavandamist. Eelmiste kõrval on tähelepanu pööratud veel direktiivi moodustamise modaalsetele konstruktsioonidele (moodustatud modaalverbi abil, nt $S a$ pead tõesti kodus kõvasti harjutama) ja verbita käsklustele (Mulle ka võid!), samuti mittemodaalsetele küsimusekujulistele direktiividele (Ise sa pärast kirjutad need sõnad ülesse, eks?) ja konditsionaali abil moodustatud soovidele, palvetele ja kaudsetele käskudele.

Karl ja Renate Pajusalu töö on keskendunud tingiva kõneviisi uurimisele, mille käigus selgus, et tingiva kõneviisi abil väljendatakse sageli soove ja palveid (nt Kas te võiksite mulle ulatada...? Nii väga tahaks...), ühtlasi on sellel, kellele palve esitatakse, tingiva kõneviisi puhul justkui kergem palve täitmisest keelduda. Tuumverbide peaks ja tahaks jmt kasutamine aitab autorite sõnul aga oma soovi pehmendada (K. Pajusalu, R. Pajusalu 2004: 265, 268). Renate Pajusalu eestisoome-vene palvete võrdlusest selgub aga, et täiskasvanute omavahelises kõnes leidub otsese käsuna vormistatud palveid vaid väga vähesel hulgal (2 palvet/küsimust 200-st) (R. Pajusalu 2014: 251).

Tiia Tulviste on uurinud direktiive emade hoidjakeeles erinevates kodustes suhtlussituatsioonides (mh söögilauavestlused, puslede kokkupanek) ning võrrelnud tulemusi Soome, Rootsi ja Ameerika emade keelekasutusega (Tulviste 2001, Tulviste jt 2003, Tulviste jt 2004). Isa direktiive on uurinud Andriela Rääbis (2012). Rääbise analüüs põhineb ühel 42-minutilisel lindistusel ja vaatluse all on isa vestlus oma 5-aastase tütrega. Keskendutud on sellele, kuidas kõnes direktiivset vooru moodustatakse ja kuidas vestluspartner sellele reageerib; materjali ei ole võrreldud ema hoidjakeele andmetega.

\section{Uurimismeetod ja andmestik}

Uuring põhineb spontaanse kõne lindistustel, vaatluse alla on võetud ühe pere kaks last ja mõlemad vanemad. Valim ei ole küll suur, kuid juhtumipõhine pikiuuring võimaldab hästi jälgida täiskasvanu keelekasutust ja selle dünaamikat, teha tähelepanekuid, kui palju kasutab vanem direktiive noorema, kui palju vanema lapsega kõneldes ja mis tüüpi direktiividega on tegemist. Nooremat last (laps 1) 
on lindistatud vanuses 7, 8, 9 ja 10 aastat, vanemat last (laps 2) vanuses 10, 11, 13 ja 14 aastat, lindistatud on igal aastal üks kord ühe tunni jooksul. Iga-aastased lindistused on toimunud eraldi nii isa kui ka emaga, puudu on lindistus vanema lapse 12. eluaastast. Uurimismaterjal hõlmab 16 tunni jagu lindistusi, milles on kokku 10950 lausungit. Lindistuste näol on tegemist argidialoogidega igapäevastes kodustes situatsioonides nagu koduste ülesannete tegemine, koos meisterdamine, koristamine, üheskoos toidu valmistamine, lauamängu mängimine jne.

Lindistused on transkribeeritud programmiga CLAN (MacWhinney 1991) ja on kättesaadavad rahvusvahelise lastekeele andmebaasi CHILDES eesti keele korpuse Kõrgesaare alamkorpuses. ${ }^{4}$ Materjali kirjapanekul on kasutatud kuuldeortograafiat (vt Hennoste 2000), kõneühikuna on aluseks võetud lausung ehk kõnevooru niisugune osa, mida piiritlevad pausid või vooruvahetus (vt täpsemalt Hennoste, Rääbis 2004: 28) ja mida suulise transkriptsiooni tavas defineeritakse selle järgi, et kahe lausungi vahele jääb vähemalt kolmesekundiline paus (vt nt Goldin-Meadow jt 2010).

Eesti viimase aja käsitlustes (R. Pajusalu 2014, Argus 2014) on enamasti lähtutud Searle’i kõneaktiteooriast (Searle 1979: 11); ka siinse artikli kontekstis on direktiiviks loetud igasugune kõneakt, mille eesmärk on panna kaasvestleja (laps) midagi tegema või mitte tegema, esindagu siis kõneakti vorm mis tahes intensiivsuseastet - käsku, keeldu, palvet, soovi, ettepanekut või muud. Transkribeeritud failidest on kogutud kõik direktiivsed lausungid ja liigitatud need tüübi järgi. Uurimismaterjali analüüsima asudes selgus, et täiskasvanute kõnes esineb väga suurel hulgal eri tüüpi direktiive ja nende liigitamisel ainult ühe või teise jaotuse alusel jääks hulk direktiive kõrvale, mistõttu otsustas siinse artikli autor Searle’i, Ervin-Trippi ning Stephany jt jaotusi kombineerida. Stephany käsitlusest on pärit keelud, kõneleja soovitud tegevuse väljendused, kultuurinormi edastused, hoiatused ja ettepanekud, Stephany käsud on jagatud Ervin-Trippi eeskujul otsesteks ja varjatud käsklusteks, kusjuures viimaste hulka on arvatud ka vihjed. Ülejäänud liigid (palve ja soov) esinevad ühe või teise nimetuse all kõigi kolme autori käsitlustes. Niisugune jaotus sobis olemasoleva keelematerjali liigitamiseks kõige paremini, kuna võimaldas määrata kõik materjalis esinenud direktiivsed kõneaktid. Siinse materjali liigitusalus on järgmine (kirjeldamiseks on kasutatud konstrueeritud näiteid):

- $\quad$ otsene käsk (Võtmed siia! Võtmed! Pane see ära! Anna sïa! Palun anna mulle..., Ulata mulle... );

- $\quad$ keeld (Ära puutu! Ei tohi võtta! Ei karju!);

- kõneleja soovitud tegevuse väljendus (See jääb nüüd sinna! Las see olla seal!);

- $\quad$ palve (Kas ma saaksin...? Kas ma tohiksin...?);

- $\quad \operatorname{soov}($ Ma tahan/tahaksin seda.);

- $\quad$ soovitus (Sa peaksid nüüd selle sinna panema. Sa ei pea karjuma. Sa võiksid nüüd õppima hakata.);

- $\quad$ ettepanek (Aga paneme selle siia, eks? Läheme nüüd hoopis õue.);

- $\quad$ hoiatus (Kui sa selle maha pillad, siis see läheb katki. Tuline! Tass on serva peal!);

4 http://childes.psy.cmu.edu/browser/index.php?url=Other/Estonian/Korgesaar/ (23.2.2015). 
- $\quad$ kaudne käsk / vihje (Kui sa selle ära paneksid, sïs... Kust ma saaksin...? See kukub sealt maha.);

- $\quad$ kultuurinormi edastamine (Sa pead ema sõna kuulama! See ei ole mänguasi. Nii ei tehta! Jalgu lauale ei panda!).

Järgnevalt on võrreldud eri tüüpi direktiivide kasutussagedust isa ja ema kõnes (kogu andmestiku sagedused on toodud lisades 1 ja 2) ning vaadeldud, kuidas see kasutussagedus vanemate kõnes aja jooksul ja lapse vanemaks saades muutub.

\section{4. Ülevaade vaatlusperioodi lindistuste suhtlus- olukordadest ja neis enim kasutatud direktiividest}

Vaatlustulemused näitasid, et peale ühe lindistuse (laps 1 vanuses 8 a, isaga) domineerisid kõigis ülejäänutes otsesed käsud (vt direktiivide jagunemist lähemalt osas 5).

(1) nii paberit paberit paberit.

(2) käi vetsus leia teksad ja mine ütle vennale ka et minek.

(3) näpud eemale.

Eri tüüpi direktiivide kasutamine lapsega kõneldes sõltub suurel määral suhtlusolukorrast. Et anda lugejale ülevaade uurimuses kasutatud eri suhtlussituatsioonidest, on järgnevalt esitatud nii isa kui ka ema kõigi lindistuste vestlusteemad koos mõne ilmekama näitega enim kasutatud või huvitavamatest direktiividest. Suhtlusolukorra järel on sulgudes esitatud lindistuses kasutatud direktiivitüübid ja nende hulk.

7 a, isaga - mängivad lauamängu (otseseid käske 57, keelde 24, kõneleja soovitud tegevuse väljendusi 9 , soovitusi 5 , ettepanekuid 4 , hoiatusi 1 , kaudseid käske / vihjeid 13); nt kaudne käsk (4), (5); keeld (6)-(8).

(4) kui me niimoodi venitama hakkame siis tal on palju raskem ma arvan.

(5) aa mäletad see tuli panna nii et otsad kokku sa saad panna siia sa saad panna siia sa võid ükskõik kuhu panna siis kui sa keerad teda.

(6) ära lollita.

(7) ära pane neid järjest kõiki palun.

(8) sina ära minu eest käi ma käin ise enda eest.

7 a, emaga - tehakse koduseid ülesandeid (otseseid käske 99, keelde 14, kõneleja soovitud tegevuse väljendusi 13 , soove 2, soovitusi 4, ettepanekuid 14, hoiatusi 2, kaudseid käske / vihjeid 8, kultuurinormi edastusi 3); nt ettepanek (9), kaudne käsk / vihje (10), (11), soov (12).

(9) ei sobi jah ja ma arvan et tead me kustutame terve selle hõhhide rea ära siit.

(10) mid ma ei saa aru kui sa nii kiiresti räägid ma ei saa mitte midagi aru.

(11) kui me sama tempoga jätkame et iga asja viis korda kustutame siis sa võibolla saad ommikuks valmis selle.

(12) ma tahan et sa teeks õigesti mitte valesti. 
8 a, isaga - täidavad lugemispäevikut (otseseid käske 5 , keelde 1 , kõneleja soovitud tegevuse väljendusi 1, ettepanekuid 1, kaudseid käske / vihjeid 6); nt kaudne käsk / vihje (13).

(13) see võib ära määrida.

8 a, emaga - ema teeb süüa, laps abistab teda (otseseid käske 6o, keelde 13, kõneleja soovitud tegevuse väljendusi 16 , soove 4 , soovitusi 8 , ettepanekuid 2, hoiatusi 2, kaudseid käske / vihjeid 10, kultuurinormi edastusi 1); nt kõneleja soovitud tegevuse väljendus (14).

(14) no las ta istub seal pausil mis taga juhtub.

9 a, isaga - valmistavad sünnipäevakaarti (otseseid käske 38, keelde 2, kõneleja soovitud tegevuse väljendusi 26 , soovitusi 1, ettepanekuid 9, hoiatusi 1, kaudseid käske / vihjeid 3); nt kõneleja soovitud tegevuse väljendus (15), soovitus (16).

(15) no las ta olla siis mõttme midagi muud välja.

(16) noh sa võiksid akata tegema õisi.

9 a, emaga - ema toimetab kodus ja aitab lapsel paberist langevarjurit meisterdada (otseseid käske 35, kõneleja soovitud tegevuse väljendusi 6, soovitusi 7, ettepanekuid 2, kaudseid käske / vihjeid 3); nt soovitus (17).

(17) no aga sinna võiks ju vähemalt kui sa üleni teda ära värvida ei viitsi sa võiks vähemalt mingid mm mustrid peale joonistada.

10 a, isaga, laps 1 - sorteerivad enne kooli algust koolitarbeid (otseseid käske 37, keelde 3, kõneleja soovitud tegevuse väljendusi 9, palveid 1, soovitusi 1, ettepanekuid 13, hoiatusi 1, kaudseid käske / vihjeid 1); nt kõneleja soovitud tegevuse väljendus (18), ettepanek (19).

(18) need ei pea ka siin olema lähevad teise sahtlisse.

(19) teeme nimodi teeme sinna unniku asjadest mis ei ole kooliasjad.

10 a, emaga, laps 1 - hakivad talveks tilli sügavkülma ja meisterdavad käepaelu (otseseid käske 28, keelde 8, kõneleja soovitud tegevuse väljendusi 12, soove 2, soovitusi 3, ettepanekuid 4, hoiatusi 1, kaudseid käske / vihjeid 2); nt kaudne käsk / vihje (20), (21).

(20) sinna mahub ikka veel.

(21) näe nüüd saad käärid jälle ära pesta.

10 a, isaga, laps 2 - joonistavad lapse palvel suurele paberile rallirada (otseseid käske 8, keelde 1, kõneleja soovitud tegevuse väljendusi 2, palveid 1 , soovitusi 1, ettepanekuid 7); nt ettepanek (22), (23).

(22) nii keerame teistpidi vao vot nii nüüd meil on palju suurem.

(23) kuule räägime mulle nüüd kuskohas mis meil on.

10 a, emaga, laps 2 - laps esmalt värvib, seejärel tehakse koos eesti keele koduseid ülesandeid (otseseid käske 75, keelde 5, kõneleja soovitud tegevuse väljendusi 4, soovitusi 10, ettepanekuid 6, hoiatusi 1, kultuurinormi edastusi 1); nt soovitus (24), hoiatus (25). 
(24) sa pead poolitama vist.

(25) kui sa nii laialt kirjutad siis sul ei mahu peale err tähe midagi ära enam.

11 a, isaga - tehakse koos matemaatika koduseid ülesandeid (otseseid käske 44, keelde 5, kõneleja soovitud tegevuse väljendusi 8, soovitusi 4, ettepanekuid 9); nt ettepanek (26), kõneleja soovitud tegevuse väljendus (27).

(26) jätame selle kevadilma präält lähme edasi mis järgmine on?

(27) tähed lähevad järgmisse ruutu juba jah nii miinus kuuskend kaheksa kaheksakend kaks.

11 a, emaga - ema toimetab kodus, vestlevad argiteemadel (otseseid käske 16, keelde 6 , kõneleja soovitud tegevuse väljendusi 2, soovitusi 3, ettepanekuid 2, kaudseid käske / vihjeid 2); nt kaudne käsk / vihje (28).

(28) ma ei kuule kui sa seal räägid.

13 a, isaga - valmistavad lapse palvel koos internetiajakirja (otseseid käske 11, kõneleja soovitud tegevuse väljendusi 2, ettepanekuid 9); nt ettepanek (29), kaudne käsk / vihje (30).

(29) vaatame kas siin on veel midagi.

(30) guugle peaks igal juhul ütlema sulle ju millal ta välja tuleb.

13 a, emaga - lobisevad ja joovad teed (otseseid käske 13, keelde 5, kõneleja soovitud tegevuse väljendusi 2, palveid 2, soovitusi 4, ettepanekuid 2, kaudseid käske / vihjeid 1, kultuurinormi edastusi 1); nt kõneleja soovitud tegevuse väljendus (31), palve (32).

(31) aa siis natuke las tõmbab veel.

(32) nii kuule kas ma saaksin kuskilt paberit ja pliiatsit?

14 a, isaga - varahommikune vestlus enne tööle-ja kooliminekut (otseseid käske 8, keelde 1, kõneleja soovitud tegevuse väljendusi 1, soovitusi 2, kaudseid käske / vihjeid 1); nt keeld (33), soovitus (34).

(33) tormad ära torma.

(34) sa pead kääd ära pesema pärast su käsi on must aga ennem ei ole mõtet kui sa viid selle rula tagasi sinna kuhu ta meil jääb präägult ootama.

14 a, emaga - ema koristab laste riidekappi, laps oma tuba (otseseid käske 40, keelde 5, kõneleja soovitud tegevuse väljendusi 1, soovitusi 10, ettepanekuid 1 , kaudseid käske / vihjeid 4); nt kaudne käsk / vihje (35), otsene käsk (36).

(35) jah mis iganes nad on sellepärast et tegelikult tuleks nüüd võtta niiske lapp ja näed teha siit ümbert kõik puhtaks telekas ka ja see on nii tolmune.

(36) meie ei vaidle üldse sel teemal.

Ülaltoodu illustreerib ilmekalt tõsiasja, et otseste käskude hulk sõltub suurel määral suhtlussituatsioonist. Otseseid käske on märgatavalt vähem niisugustes situatsioonides, kus lapsel ei ole õppija või abistaja rolli (siinse materjali hulgas näiteks lindistused, kus lapse soovil täidetakse lugemispäevikut, joonistatakse rallirada, toimetatakse kodus, koostatakse internetiajakirja, juuakse teed või vesteldakse niisama päeva hakul), kõige direktiivirohkemad on aga olukorrad, kus 
lapsega lahendatakse koduseid ülesandeid. Ootamatult direktiivirohke on ka isa ja lapse lauamängu-lindistus, milles isal esines rohkem direktiive kui üheski teises lindistuses.

Tasub tähele panna, et nii mõnigi näitelause ei jäta ehk muljet direktiivsest kõneaktist põhjusel, et kirjalik tekst ei suuda edastada kõneleja hääletooni, nt (10), (21), (28), (30), (32), (35). Näite (35) puhul andis ema hääletoon selgelt mõista, et ta ootab just lapselt, et too võtaks nüüd kohe lapi ja puhastaks teleri ümbruse ära, mitte ei öelnud lihtsalt suusoojaks, et keegi peaks millalgi selle ära tegema.

Selleks, et täpselt aru saada, mida mingi lausungiga on silmas peetud, on oluline teada konteksti ja mõnel puhul ka kõnelejate tausta. Näidetes (10) ja (28) väljendab ema hääletoon samuti, et ta ootab, et laps kordaks öeldut selgemini või valjemini, ent taust lisab näites (10) teadmise, et laps on võrdlemisi kehva diktsiooniga ja tal on korduvalt palutud selgemini rääkida. Teisel puhul (28) saame varasema dialoogi põhjal aru, et laps läks ruumist ära ja räägib nüüd kusagil eemal. Ema vihje, et ta ei kuule, kui laps seal räägib, on selge märguanne, et laps tuleks ruumi tagasi.

\section{Eri tüüpi direktiivid isa ja ema lapsele suunatud kõnes}

\subsection{Direktiivide jagunemine ning nende dünaamika isa ja ema kõnes}

Kirjeldan esmalt eri tüüpi direktiivide jagunemist keelematerjalis kogu vaatlusperioodi jooksul üldiselt. Isa kõne 2300 lausungis esines kokku 398 ja ema kõne 3228 lausungis 612 direktiivset kõneakti, eri tüüpi direktiivide jaotusest annab ülevaate joonis 1. (Arvandmed on toodud lisades 1 ja 2 ning tabelis 1.)

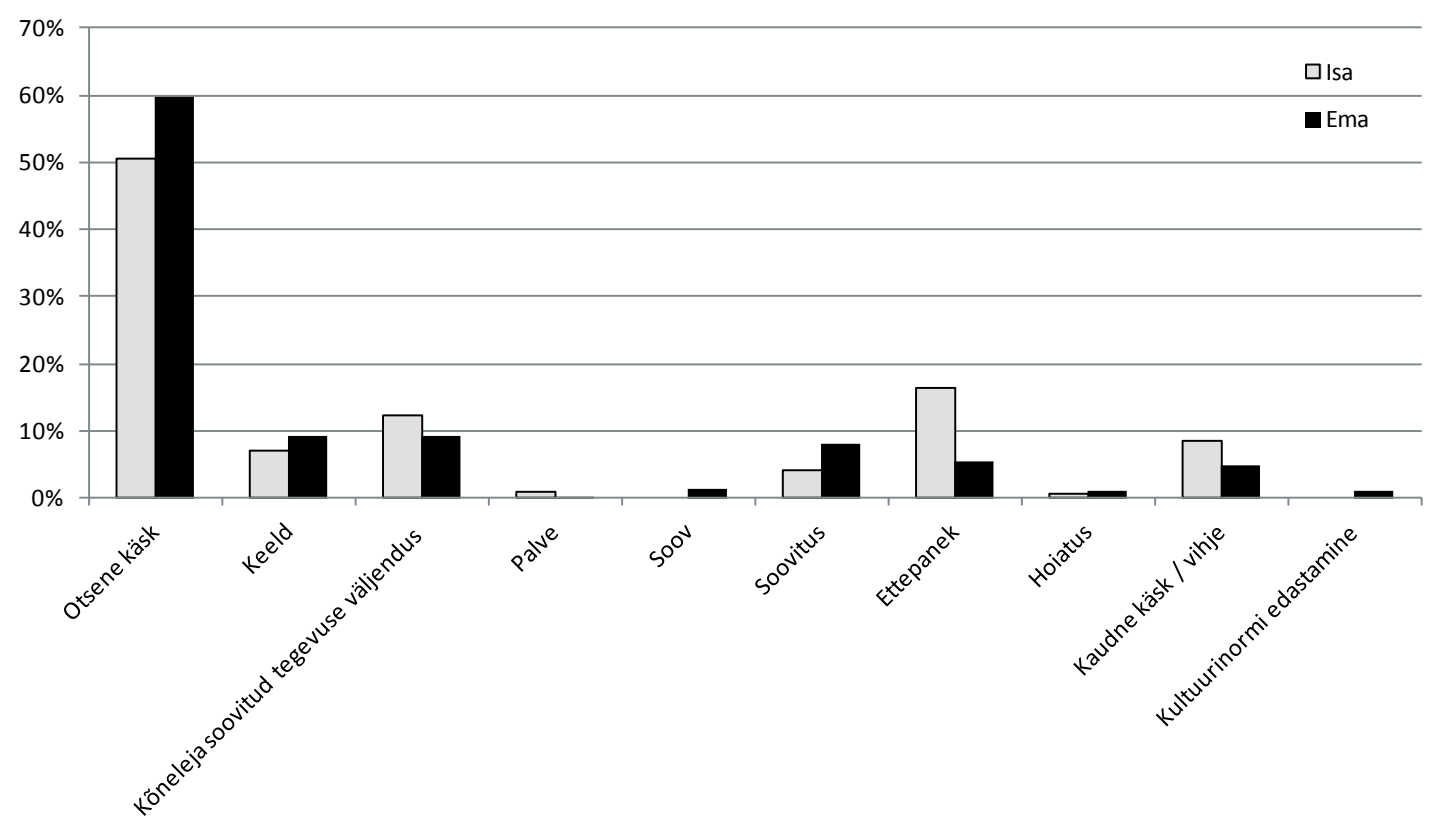

Joonis 1. Eri tüüpi direktiivide jagunemine andmestikus 
Nagu jooniselt näha, on mõlema vanema kõnes kõige sagedasemad otsesed käsud. Need domineerivad enamikus lindistustest, otseste käskude osakaal on isa kõnes keskmiselt 50 ja ema kõnes 60 protsenti ning jääb lindistuste lõikes isa kõnes 36 ja 63, ema kõnes aga 43 ja 74 protsendi vahele. Veel hakkab silma, et ema kõnes jagunevad kaudsed direktiivid märksa ühtlasemalt, kaetud on ka need direktiivitüübid, mida isa kõnes ei esinenud: oma soovi väljendab ema kokku kaheksal korral (1,3\% juhtudest) ja kultuurinormi edastab ta direktiivsel moel kuuel korral (1\% juhtudest).

Tulemused võimaldavad järeldada, et mõlemad vanemad on suhtluses lastega võrdlemisi direktiivsed, kasutades selleks, et last midagi tegema või mitte tegema panna, kõige enam (üle 50\%) otseseid käske. Muude direktiivide jagunemise põhjal võib öelda, et ema kasutab samal määral keeldusid ja kõneleja soovitud tegevuse väljendamist (mõlemat 9\%) ning annab lapsele soovitusi (8\%). Isa väljendab seevastu võrdlemisi palju (12\%) soovi lapse tegevuse kohta (nt Need lähevad ruuduliste vihikute hunnikusse), kuid peaasjalikult (16\%) esitab ta pigem ettepanekuid edasise tegevuse kohta (Aga teeme nii, et...), samas kui kogu vaatlusperioodi jooksul ei esine isa kõnes ainsatki soovi väljendust. Samuti on huvitav fakt, et isa ei edasta lapsele direktiive kultuurinormi kaudu. Palveid ja hoiatusi esineb mõlema vanema kõnes võrdselt vähe, alla $1 \%$.

Kui vaadelda muutusi, mis ema ja isa direktiivikasutuses aja jooksul aset leiavad (tabel 1; absoluutarvud on toodud lisades 1 ja 2), tuleb märkida, et otseste käskude hulk mõlema vanema kõnes läbib küll mõningaid tõuse ja langusi, ent siiski ei saa väita, et nende osakaal kõigi direktiivitüüpide hulgas aja jooksul selgelt kasvaks või kahaneks. Otseseid keeldusid kasutab isa kõige rohkem (21\%) just väiksema lapsega vesteldes, ema kõnes nende hulk varieerub. Kõneleja soovitud tegevust väljendavate direktiivide hulk isa kõnes on vaatlusperioodi algul sama suur kui ema kõnes - mõlemal 8\% - ja see kasvab mõlema vanema lindistustes, saavutades isa kõnes maksimumi (33\%) 9-aastase ja ema kõnes (20\%) 10-aastase lapsega kõneldes. Pärast seda hakkab näitaja mõlema vanema kõnes langema ning jõuab isa kõnes 14-aastase lapsega vestlemisel tagasi alguspunkti (8\%), ema kõnes aga koguni 1,6\%-ni. Soovituste hulk ema kõnes läbib vaatlusperioodi kestel üsnagi kindla tõusu (vaatlusperioodi algul 2,5\%, lõpus 16\%), kuid isa kõnes leiab viimase lindistusega aset soovituste hulga järsk kasv (15\%), pärast seda kui see on varem kõikunud 1\% ja 6\% vahel. Ettepanekud on isa kõnes otseste käskude järel levinuimad direktiivid, mille hulk ajaga hüppeliselt kasvab, jõudes 13-aastase lapsega suhtlemisel koguni 41\%-ni, mistõttu on ootamatu, et viimases lindistuses ei esine ilmselt vestlussituatsioonist tingituna ühtki ettepaneku vormis direktiivi. Ema kõne ettepanekute hulk püsib aga vaatlusperioodi vältel võrdlemisi stabiilne, tehes läbi vaid paar langust. Kõige rohkem ettepanekuid (9\%) kasutas ema 7-aastase lapsega vesteldes.

Veel hakkab silma, et hoiatusi andsid mõlemad vanemad direktiivsel moel edasi pigem nooremale lapsele, pärast 10. eluaastat neid kummagi vanema kõnes enam ei esinenud. Ka kaudsete käskude ja vihjete hulk oli ema kõnes võrdlemisi stabiilne (3-8\%), kuid isa kõnes oli see 7-aastase lapsega kõneldes 11\% ja 8-aastasega kõneldes koguni 42\%. Pärast niisugust järsku tõusu aga nende hulk vähenes niisama järsult ja püsis kuni vaatlusperioodi lõpuni samuti $4 \%$ ja $8 \%$ vahel, puududes mõnes lindistuses sootuks. 
Tabel 1. Eri tüüpi direktiivide osakaal protsentides isa/ema kõnes

\begin{tabular}{|c|c|c|c|c|c|c|c|c|c|c|}
\hline Laps ja vanus & $\begin{array}{c}\text { Otsene } \\
\text { käsk }\end{array}$ & Keeld & $\begin{array}{l}\text { Kõneleja } \\
\text { soovitud } \\
\text { tegevuse } \\
\text { väljendus }\end{array}$ & Palve & Soov & Soovitus & $\begin{array}{l}\text { Ette- } \\
\text { panek }\end{array}$ & $\begin{array}{c}\text { Hoia- } \\
\text { tus }\end{array}$ & $\begin{array}{c}\text { Kaudne } \\
\text { käsk / } \\
\text { vihje }\end{array}$ & $\begin{array}{c}\text { Kultuuri- } \\
\text { normi } \\
\text { edasta- } \\
\text { mine }\end{array}$ \\
\hline Laps 1, 7-aastane & $\begin{array}{c}50,4 / \\
62,3 \\
\end{array}$ & $\begin{array}{c}21,2 / \\
8,8\end{array}$ & $\begin{array}{c}8,0 / \\
8,2 \\
\end{array}$ & - & $\begin{array}{l}-/ \\
1,3\end{array}$ & $\begin{array}{c}4,4 / \\
2,5\end{array}$ & $\begin{array}{c}3,5 / \\
8,8\end{array}$ & $\begin{array}{c}0,9 / \\
1,3\end{array}$ & $\begin{array}{c}11,5 / \\
5,0\end{array}$ & $\begin{array}{l}-1 \\
1,9\end{array}$ \\
\hline Laps 1, 8-aastane & $\begin{array}{c}35,7 / \\
51,7\end{array}$ & $\begin{array}{l}7,1 / \\
11,2\end{array}$ & $\begin{array}{l}7,1 / \\
13,8\end{array}$ & - & $\begin{array}{l}-1 \\
3,4\end{array}$ & $\begin{array}{l}-1 \\
6,9\end{array}$ & $\begin{array}{c}7,1 / \\
1,7\end{array}$ & $\begin{array}{l}-/ \\
1,7\end{array}$ & $\begin{array}{c}42,9 / \\
8,6\end{array}$ & $\begin{array}{l}-/ \\
0,9\end{array}$ \\
\hline Laps 1, 9-aastane & $\begin{array}{c}47,5 / \\
66,0\end{array}$ & $\begin{array}{c}2,5 / \\
-\end{array}$ & $\begin{array}{c}32,5 / \\
11,3\end{array}$ & - & - & $\begin{array}{l}1,3 / \\
13,2\end{array}$ & $\begin{array}{c}11,3 / \\
3,8\end{array}$ & $\begin{array}{c}1,3 / \\
-\end{array}$ & $\begin{array}{c}3,8 / \\
5,7\end{array}$ & - \\
\hline Laps 1, 10-aastane & $\begin{array}{c}56,1 / \\
46,7\end{array}$ & $\begin{array}{l}4,5 / \\
13,3\end{array}$ & $\begin{array}{c}13,6 / \\
20,0\end{array}$ & $\begin{array}{c}1,5 / \\
-\end{array}$ & $\begin{array}{l}-1 \\
3,3\end{array}$ & $\begin{array}{c}1,5 / \\
5,0\end{array}$ & $\begin{array}{c}19,7 / \\
6,7\end{array}$ & $\begin{array}{c}1,5 / \\
1,7\end{array}$ & $\begin{array}{c}1,5 / \\
3,3\end{array}$ & - \\
\hline Laps 2, 10-aastane & $\begin{array}{c}40,0 / \\
73,5\end{array}$ & $\begin{array}{c}5,0 / \\
4,9\end{array}$ & $\begin{array}{c}10,0 / \\
3,9\end{array}$ & $\begin{array}{c}5,0 / \\
-\end{array}$ & - & $\begin{array}{c}5,0 / \\
9,8\end{array}$ & $\begin{array}{c}35,0 / \\
5,9\end{array}$ & $\begin{array}{l}-1 \\
1,0\end{array}$ & - & $\begin{array}{l}-1 \\
1,0\end{array}$ \\
\hline Laps 2, 11-aastane & $\begin{array}{c}62,9 / \\
51,6\end{array}$ & $\begin{array}{l}7,1 / \\
19,4\end{array}$ & $\begin{array}{c}11,4 / \\
6,5\end{array}$ & - & - & $\begin{array}{c}5,7 / \\
9,7\end{array}$ & $\begin{array}{c}12,9 / \\
6,5\end{array}$ & - & $\begin{array}{l}-1 \\
6,5\end{array}$ & - \\
\hline Laps 2, 13-aastane & $\begin{array}{c}50,0 / \\
43,3\end{array}$ & $\begin{array}{l}-/ \\
16,7\end{array}$ & $\begin{array}{c}9,1 / \\
6,7\end{array}$ & $\begin{array}{l}-1 \\
6,7\end{array}$ & - & $\begin{array}{c}-1 \\
13,3\end{array}$ & $\begin{array}{c}40,9 / \\
6,7\end{array}$ & - & $\begin{array}{l}-1 \\
3,3\end{array}$ & $\begin{array}{l}-1 \\
3,3\end{array}$ \\
\hline Laps 2, 14-aastane & $\begin{array}{c}61,5 / \\
65,6\end{array}$ & $\begin{array}{c}7,7 / \\
8,2\end{array}$ & $\begin{array}{c}7,7 / \\
1,6\end{array}$ & - & - & $\begin{array}{c}15,4 / \\
16,4\end{array}$ & $\begin{array}{l}-1 \\
1,6\end{array}$ & - & $\begin{array}{c}7,7 / \\
6,6\end{array}$ & - \\
\hline Keskmine & $\begin{array}{c}50,5 / \\
59,8\end{array}$ & $\begin{array}{c}6,9 / \\
9,2\end{array}$ & $\begin{array}{c}12,4 / \\
9,2\end{array}$ & $\begin{array}{c}0,8 / \\
0,3\end{array}$ & $\begin{array}{l}-1 \\
1,3\end{array}$ & $\begin{array}{c}4,2 / \\
8,0\end{array}$ & $\begin{array}{c}16,3 / \\
5,4\end{array}$ & $\begin{array}{c}0,5 / \\
1\end{array}$ & $\begin{array}{c}8,4 / \\
4,9\end{array}$ & $\begin{array}{c}-1 \\
1\end{array}$ \\
\hline
\end{tabular}

\subsection{Muutused direktiivide kasutussageduses vaatlusperioodi jooksul}

Tabelis 2 on esitatud nii isa kui ka ema lausungite koguhulk igas lindistuses, direktiivide arv ja nende osakaal protsentides.

Tabel 2. Direktiivide arv ja osakaal lapsele suunatud kõne lausungites

\begin{tabular}{|l|c|c|c|c|c|c|}
\hline Laps ja vanus & $\begin{array}{c}\text { Isa } \\
\text { lausungeid } \\
\text { kokku }\end{array}$ & $\begin{array}{c}\text { Isa } \\
\text { direktiivide } \\
\text { koguhulk }\end{array}$ & $\begin{array}{c}\text { Isa } \\
\text { direktiivide } \\
\text { osakaal }\end{array}$ & $\begin{array}{c}\text { Ema } \\
\text { Iausungeid } \\
\text { kokku }\end{array}$ & $\begin{array}{c}\text { Ema } \\
\text { direktiivide } \\
\text { koguhulk }\end{array}$ & $\begin{array}{c}\text { Ema } \\
\text { direktiivide } \\
\text { osakaal }\end{array}$ \\
\hline Laps 1, 7-aastane & 574 & 113 & $20 \%$ & 387 & 159 & $41 \%$ \\
\hline Laps 1, 8-aastane & 217 & 14 & $7 \%$ & 398 & 116 & $29 \%$ \\
\hline Laps 1, 9-aastane & 238 & 80 & $34 \%$ & 411 & 53 & $13 \%$ \\
\hline Laps 1, 10-aastane & 346 & 66 & $19 \%$ & 382 & 60 & $16 \%$ \\
\hline Laps 2, 10-aastane & 156 & 20 & $13 \%$ & 487 & 102 & $21 \%$ \\
\hline Laps 2, 11-aastane & 356 & 70 & $20 \%$ & 401 & 31 & $8 \%$ \\
\hline Laps 2, 13-aastane & 163 & 22 & $13 \%$ & 391 & 30 & $8 \%$ \\
\hline Laps 2, 14-aastane & 250 & 13 & $6 \%$ & 371 & 61 & $16 \%$ \\
\hline Kokku & 2300 & 398 & $17 \%$ & 3228 & 612 & $19 \%$ \\
\hline
\end{tabular}


Materjalis ei ilmne direktiivide osakaalu järjekindlat vähenemist lapse vanemaks saades. Isa kõnes näitab direktiivide kasutussagedus märgatavat langust kahel viimasel aastal, ema kõnes toimub samasugune langus lapse vanuses 11 ja 13 eluaastat, kuid ema viimase lindistuse direktiivide hulga kasv kahekordseks annab põhjust oletada, et muutused on tingitud pigem vestlussituatsioonist. Ehkki kõik lindistused on tehtud tavapärastes kodustes situatsioonides, tuleb siiski eristada suhtlusolukordi, kus täiskasvanud on direktiivsemad. Nimetatud olukorrad ei hõlma ainult ühist koduste ülesannete tegemist (mis ilmselt kaldub küll olema kõige direktiivirohkem), vaid ka muid koostööolukordi nagu toa koristamine, koolitarvete sorteerimine, sünnipäevakaardi meisterdamine ja elektroonilise ajakirja koostamine, tilli lõikamine, vormeliraja joonistamine jne, kus täiskasvanul on täita õpetaja ja juhendaja roll. Üsnagi direktiivirohke oli aga ka lindistus, kus isa ja laps mängisid koos lauamängu (Sinu kord! Tõmba kaarti ka! Käi nüüd! Veereta! jne). Vähem direktiive esines seevastu lindistustes, kus sihipärane tegevus puudus. Näiteks isa viimases, 14-aastase lapsega salvestatud lindistuses puudusid üllatuslikult isale varem nii omased olnud ettepanekud, seevastu kasutas ta seni harvemini esinenud soovitusi. Täiskasvanu ja laps viibisid selle lindistuse ajal lihtsalt hommikul enne tööle- ja kooliminekut samas toas, mõlemad olid parasjagu unised ja kordamööda püüti vestlust ülal hoida. Igapäevaelus on niisugused vestlused pigem haruldased.

Kui siinkirjutaja viimatine uurimus isade ja emade lastele suunatud kõne koguhulga ja eri tüüpi lausungite kasutamise kohta kinnitas, et isad ja emad kõnelevad lastega üldjoontes ühepalju ja ka eri lausungitüüpe (mh direktiive) kasutatakse peaaegu võrdselt (Kõrgesaar 2014b), siis siinsed tulemused on mõnevõrra vastuolulised, näidates, et kõigi lindistuste peale kokku esines isa kõnes 2300 ja ema kõnes 3228 lausungit. Sama üllatav oli tulemus direktiivide kasutussageduse kohta, millest selgus, et isa lausungite hulgas oli direktiive 398, ema kõnes aga esines enam kui 200 direktiivi rohkem - 612. Samas kinnitab direktiivide osakaal kõigist lausungitest siiski varasemaid tulemusi, jäädes isa kõnes $17 \%$ ja ema kõnes $19 \%$ juurde (vt Kõrgesaar 2014, kus kahe eri isa ja ema lapsele suunatud kõne direktiivide osakaal kõigist lausungitest jäi 10\% ja 15\% piiresse).

\section{Kokkuvõtteks}

Uurimuse ülesandeks oli selgitada, kuidas jagunevad eri tüüpi direktiivid isa ja ema kõnes ning kuidas muutub direktiivikasutus üldiselt sedamööda, mida vanema lapsega täiskasvanu kõneleb. Ehkki analüüsitulemused kinnitavad, et direktiivide hulk täiskasvanu kõnes aja jooksul üldiselt väheneb, tuleb siiski märkida, et otsesed käsud on 9-14-aastase lapsega suheldes nii isa kui ka ema kõnes levinuimad direktiivid, mis moodustavad enam kui poole vestluses kasutatavatest direktiividest.

Direktiivikasutuse suhtlusolukorrapõhine vaatlus näitab, et kõige enam otseseid käske esines neis suhtlussituatsioonides, kus lapsel oli õppija või abistaja roll, täiskasvanul aga õpetaja-instrueerija roll. Vähem otseseid käske leidus olukordades, kus tehti küll midagi koos (meisterdamine, joonistamine), kuid lapse palvel. Isa kõnes esines arvuliselt kõige rohkem otseseid käske vaatlusperioodi esimeses lindistuses, kus mängiti 7-aastase lapsega lauamängu, ja osakaaluna kõigist direktiividest lindistuses, kus valmistati 9-aastase lapsega sünnipäevakaarti. Ema kõne puhul 
langesid nii arvuline ülekaal kui ka osakaal kokku samuti esimeses lindistuses, kus lahendati 7-aastase lapsega koduseid ülesandeid.

Tulemused kinnitavad autori varasemat väidet, et emad ja isad kasutavad direktiive üsnagi samal määral, mistõttu ei saa väita, et ema kõne oleks selgelt direktiivsem kui isa oma või vastupidi. Kindlasti võib aga väita, et ema kõnes jagunevad eri direktiivitüübid ühtlasemalt ja erinevalt isast kasutab ema direktiive vähesel määral ka selleks, et anda lapsele edasi üldisi kultuuri- ja käitumisnorme. Kuivõrd siinse uurimuse näol oli tegemist juhtumianalüüsiga, mis põhines vaid ühe pere vanemate keelekasutusel, oleks üldistuste tegemiseks otstarbekas viia edaspidi läbi järgmine, laia valimi põhjal tehtud uurimus, milleks praegu CHILDES-i andmebaasi eesti lastekeele korpuses piisav võrdlusmaterjal puudub. Samuti tasuks järgmistes hoidjakeeleuurimustes pöörata rohkem tähelepanu isade hoidjakeelele, et selgitada välja, kas üldse ja kui, siis mille poolest erineb isade hoidjakeel emade omast.

\section{Viidatud kirjandus}

Argus, Reili 2010. Mida teeb tegema-verb hoidjakeeles. [Constructions with the verb tegema 'do, make' in child directed speech.] - Eesti ja soome-ugri keeleteaduse ajakiri ESUKA / Journal of Estonian and Finno-Ugric Linguistics JEFUL, 1 (2), 17-34.

Argus, Reili 2014. Deontilise modaalsuse omandamine. Palved. Esimene sissevaade. Ettekanne TLÜ EKKI teadusseminaris 6. mail 2014.

Argus, Reili; Kõrgesaar, Helen 2012. Hakkama-verb lapsekeeles: kas aspektilisuse või tuleviku tähistaja? ["Hakkama”-verb in child language: A marker of aspectuality or future?] Emakeele Seltsi aastaraamat, 57 (2011), 9-24. http://dx.doi.org/10.3176/esa57.01

Argus, Reili; Kõrgesaar, Helen 2014. Sõnaliigid eesti lapse kõnes ja lapsele suunatud kõnes. [Word classes in the child's speech and in the child-directed speech.] - Eesti Rakenduslingvistika Ühingu aastaraamat, 10, 39-53. http://dx.doi.org/10.5128/ERYa10.03

Craven, Alexandra; Potter, Jonathan 2010. Directives: Entitlement and contingency in action. Discourse Studies, 12 (4), 419-442. http://dx.doi.org/10.1177/14614456610370126

Curl, Traci; Drew, Paul 2008. Contingency and action: A comparison of two forms of requesting. - Research on Language and Social Interaction, 41 (2), 129-53. http://dx.doi. org/10.1080/08351810802028613

EKG II = Erelt, Mati; Kasik, Reet; Metslang, Helle; Rajandi, Henno; Ross, Kristiina; Saari, Henn; Tael, Kaja; Vare Silvi 1993. Eesti keele grammatika II. Süntaks. [Estonian Grammar II. Syntax.] Tallinn: Eesti TA Keele ja Kirjanduse Instituut.

Ervin-Tripp, Susan 1976. "Is Sybil There?” The structure of some American English directives. Language in Society, 5 (1), 25-66. http://dx.doi.org/10.1017/So047404500006849

Goldin-Meadow, Susan; Hedges, Larry; Huttenlocher, Janellen; Levine, Susan; Raudenbush, Stephen; Small, Steven 2010. Language Development Project 2002-2012. University Chicago. http://joyrex.spc.uchicago.edu/ldp/docs/index.html (24.9.2014).

Hennoste, Tiit 2000. Suulise eesti keele uurimine: transkriptsioon, taust ja korpus. [Research into spoken Estonian: Transcription, background, corpus.] - Keel ja Kirjandus, 2, 91-106.

Hennoste, Tiit; Rääbis, Andriela 2004. Dialoogiaktid eesti infodialoogides: tüpoloogia ja analüüs. [Dialogue Acts in Estonian Information Dialogues: Typology and Analysis.] Tartu: Tartu Ülikooli kirjastus. http://hdl.handle.net/10062/18995

Hill, Elizabeth 2009. Do mothers and fathers differ in their speech styles when speaking to their children? Are there speaker gender effects on parents' language behaviour? Innervate: Leading Undergraduate Work in English Studies, 2, 163-182. 
Kõrgesaar, Helen 2014a. Küsimused eesti lapsele suunatud kõnes leedu ja vene keele taustal. [Interrogatives in Estonian child-directed speech.] - Eesti Rakenduslingvistika Ühingu aastaraamat, 10, 193-207. http://dx.doi.org/10.5128/ERYa10.12

Kõrgesaar, Helen 2014b. Eesti isade-emade hoidjakeel: kes küsib, kes käsutab, kes räägib rohkem? [Estonian fathers' and mothers' child-directed speech: Who asks more questions, who gives orders, and who speaks more?] - Krista Kerge (Toim.). Uurimusi keele omandamisest, õppimisest ja korpustest. Tallinna Ülikooli eesti keele ja kultuuri instituudi toimetised 16. Tallinn, 59-82.

Kõrgesaar, Helen; Kapanen, Airi 2015. Kui lapsega ei räägi üksnes ema: valik termineid eesti laste- ja hoidjakeele kohta. - Eesti Rakenduslingvistika Ühingu aastaraamat, 11, 177-188. http://dx.doi.org/10.5128/ERYa11.11

Leaper, Campbell; Anderson, Kristin J.; Sanders, Paul 1998. Moderators of gender effects on parents' talk to their children: A meta-analysis. - Developmental Psychology, 34 (1), 3-27. http://dx.doi.org/10.1037/0012-1649.34.1.3

Leech, Kathryn A.; Salo, Virginia C.; Rowe, Meredith L.; Cabrera, Natasha J. 2013. Father input and child vocabulary development: The importance of wh-questions and clarification requests. - Seminars in Speech and Language, 34 (4), 249-259. http:// dx.doi.org/10.1055/s-0033-1353445

MacWhinney, Brian 1991. The CHILDES project: Tools for Analyzing Talk. Hillsdale, NJ: Lawrence Erlbaum Associates Inc.

Matychuk, Paul 2005. The role of child-directed speech in language acquisition: A case study. Language Sciences, 27 (3), 301-397. http://dx.doi.org/10.1016/j.langsci.2004.04.004

Metslang, Helle 2004. Imperative and related matters in everyday Estonian. - Linguistica Uralica, 40 (4), 243-256.

Olson, Sheryl L. 1986. Mother-child interaction and children's speech progress: A longitudinal study of the first two years. - Merrill-Palmer Quarterly, 32 (1), 1-20.

Pajusalu, Renate 2014. Palved eesti, soome ja vene keeles: Grammatika pragmaatika teenistuses. [Requests in Estonian, Finnish and Russian: Grammar and pragmatics.] - Eesti Rakenduslingvistika Ühingu aastaraamat, 10, 241-257. http://dx.doi.org/10.5128/ ERYa10.15

Pajusalu, Karl; Pajusalu, Renate 2004. The conditional in everyday Estonian: It's form and functions. - Linguistica Uralica, 40 (4), 257-269.

Pratt, Michael W.; Kerig, Patricia K.; Cowan, Philip A.; Pape Cowan, Carolyn 1992. Family worlds: Couple satisfaction, parenting style, and mothers' and fathers' speech to young children. - Merrill-Palmer Quarterly, 38 (2), 245-262.

Rääbis, Andriela 2012. Direktiivisekventsid isa ja tütre suhtluses: juhtumianalüüs. [Directive sequences in a conversation of father and daughter: A case study.] - Eesti Rakenduslingvistika Ühingu aastaraamat, 8, 213-230. http://dx.doi.org/10.5128/ERYa8.14

Searle, John 1976. A classification of illocutionary acts. - Language Society, 5 (1), 1-23. http://dx.doi.org/10.1017/So047404500006837

Searle, John 1979. Expression and Meaning: Studies in the Theory of Speech Acts. Cambridge: Cambridge University Press. http://dx.doi.org/10.1017/CBO9780511609213

Snow, Catherine E. 1977. The development of conversation between mothers and babies. - Journal of Child Language, 4 (1), 1-22. http://dx.doi.org/10.1017/S0305000900000453

Stephany, Ursula; Aksu-Koç, Ayhan; Voeikova, Maria D. 2013. The category of modality: A crosslinguistic study of its development. - Ettekanne rahvusvahelisel pre- ja protomorfoloogia projekti aastakonverentsil Viinis, 21.-23. veebruaril 2013.

Tamm, Anne; Argus, Reili; Suurmäe, Kadri 2014. Evidentsiaalid: kas uskuda või mitte? Teabe vormi mõju eesti koolieelikute käitumisele. [Evidential sentences guiding Estonian preschoolers' exploration of novel objects and their properties.] - Emakeele Seltsi aastaraamat, 59 (2013), 244-262. http://dx.doi.org/10.3176/esa59.13 
Tulviste, Tiia 2001. Can variation in mother-child interaction be explained by context and collectivistic attitudes? - Applied Psycholinguistics, 22 (4), 541-553. http://dx.doi. org/10.1017/S0142716401004039

Tulviste, Tiia 2003. Mothers'conversational styles across cultures. The case of Estonia, Finland, Sweden and the U.S. - Proceedings of the IACCP XVIth Congress, Yogyakarta, Indoneesia, 15.-19. juuli 2002.

Tulviste Tiia; Mizera, Luule; De Geer, Boel; Tryggvason, Marja-Terttu 2003. A comparison of Estonian, Swedish, and Finnish mothers' controlling attitudes and behaviour. - International Journal of Psychology, 38 (1), 46-53. http://dx.doi. org/10.1080/00207590244000278

Tulviste, Tiia; Mizera, Luule; De Geer, Boel 2004. Expressing communicative intents in Estonian, Finnish, and Swedish mother-adolescent interactions. - Journal of Child Language, 31 (4), 801-819. http://dx.doi.org/10.1017/S0305000904006488

\section{Võrgumaterjalid}

CHILDES, Kõrgesaare alamkorpus. http://childes.psy.cmu.edu/browser/index.php?url= Other/Estonian/Korgesaar/ (5.2.2015).

Helen Kõrgesaar (Tallinna Ülikool) uurib eesti hoidjakeelt, selle dünaamikat ja mõju lapse kõne arengule.

Narva mnt 25, 10120 Tallinn, Estonia

helen.korgesaar@gmail.com 


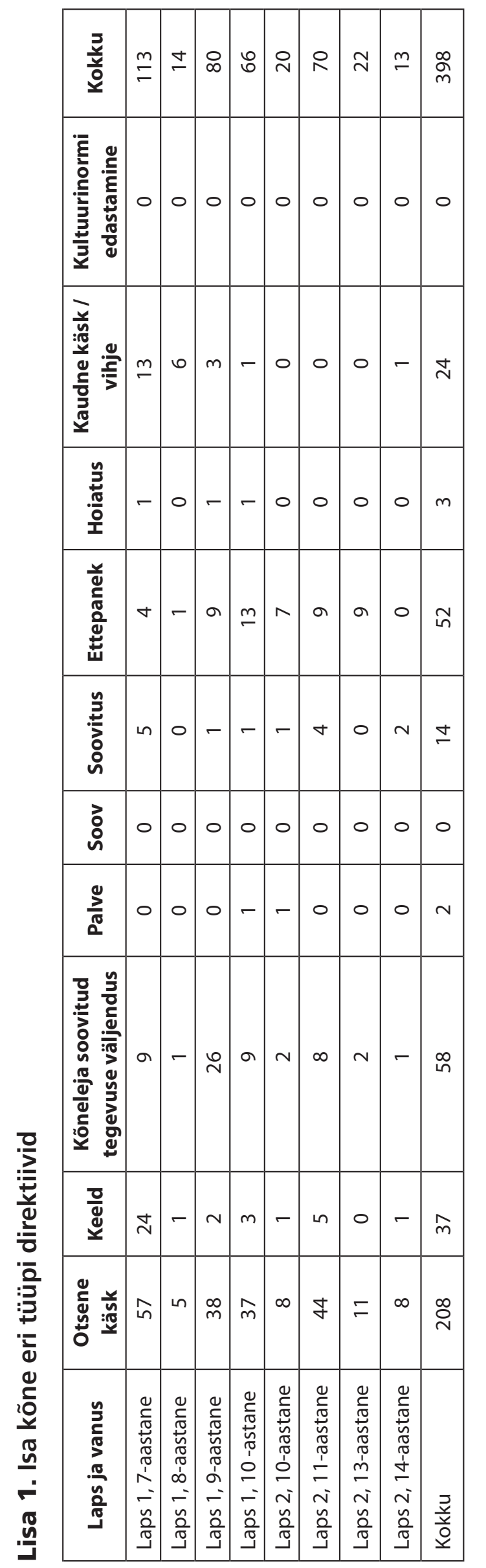

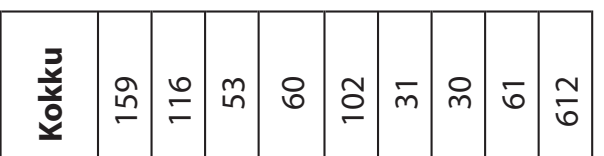

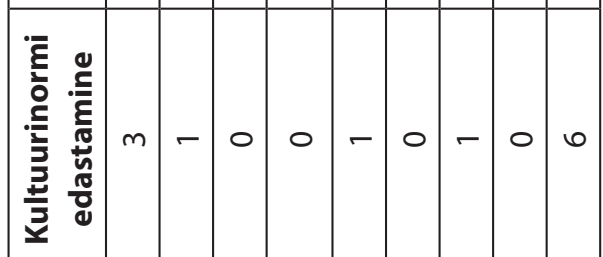

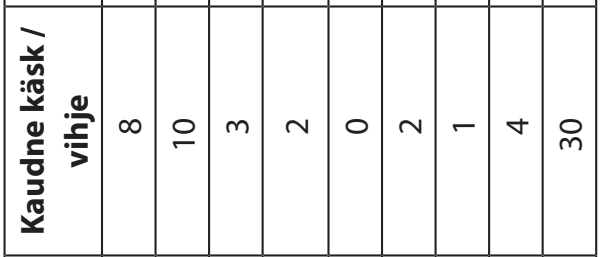

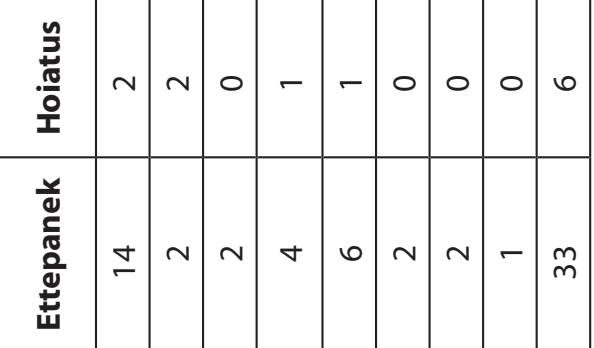

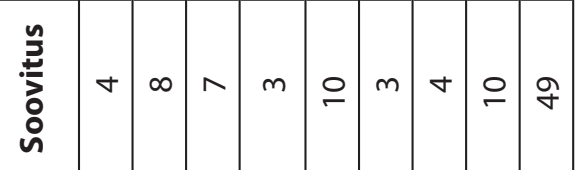

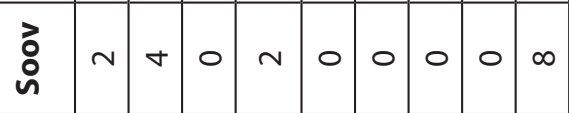$$
\begin{array}{ll|l|l|l|l|l|l|l|l}
\frac{8}{2} & 0 & 0 & 0 & 0 & 0 & 0 & n & 0 & n
\end{array}
$$

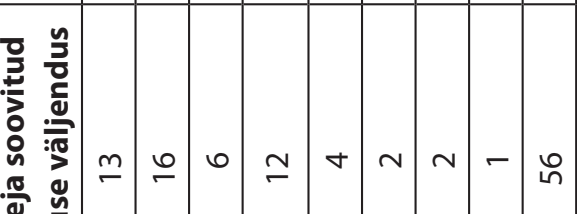

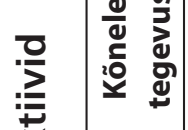

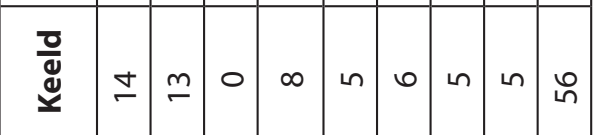

:윽

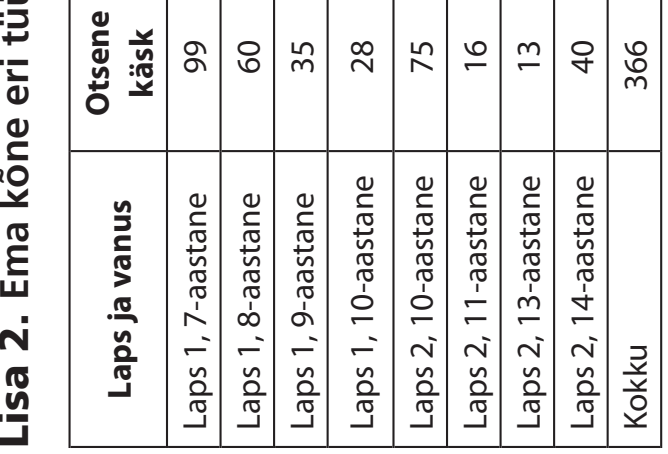




\title{
DIRECTIVE SPEECH ACTS AND THE DYNAMICS OF THEIR USAGE IN FATHER'S AND MOTHER'S SPEECH: A CASE STUDY
}

\author{
Helen Kõrgesaar \\ Tallinn University
}

The aim of the article is to give an overview of directive speech acts in Estonian child-directed speech. Two school-age children from the same family and their dialogues with both parents individually are under observation. A longitudinal study has been used as the method (one child has been regularly recorded from ages 7 to 10 , the other from ages 10 to 14), including 16 hours of audio material. All directive speech acts have been singled out from the parents' speech and classified into imperatives, hints, prohibitions, statements of an addressee's desired actions, permissions, speaker's wishes, suggestions, hortatives, warnings and statements of social rules. Based on the analysis, comparisons are made between the mother's and father's speech with regard to the usage of different types of directives, and the dynamics of using directives when the child is growing as well as in situations of communication have been examined.

Although the results of the analysis confirm that the amount of directives in adults' speech decreases over time, it should be pointed out that imperatives are the most common directives in both the father's and mother's speech when communicating with a child aged between 7 and 14, comprising more than half of the directives used in conversation. The results confirm the author's previous assertion that mothers and fathers use comparable amounts of directives, ruling out the claim that the mother's speech has clearly more directives than that of the father or vice versa. However, it can surely be said that different types of directives are divided more equally in the mother's speech and unlike the father, the mother uses directives (although in a very small amount) in order to teach the child cultural norms and social rules.

Keywords: caregivers' speech, child-directed speech, Estonian 